\title{
PENGEMBANGAN MEDIA PEMBELAJARAN VIDEO BAHASA JEPANG BERBASIS ADOBE FLASH UNTUK SEKOLAH DASAR DI BALI
}

\author{
N.K.A. Adrianti ${ }^{1}$, D.M.S. Mardani ${ }^{2}$, I.W. Sadyana ${ }^{3}$ \\ ${ }^{123}$ Jurusan Bahasa Asing, Universitas Pendidikan Ganesha, Singaraja \\ e-mail : adrianti414@gmail.com, desak.mardani@undiksha.ac.id, \\ wayan.sadyana@undiksha.ac.id
}

\begin{abstract}
Abstrak
Penelitian ini bertujuan untuk menghasilkan media pembelajaran video berbasis adobe flash yang sesuai dengan kurikulum 2013 untuk Sekolah Dasar di Bali. Pengembangan media pembelajaran ini menggunakan model four- $D(4 \mathrm{D})$, namun pegembangan media dilakukan sampai pada tahap Develop (pengembangan) karena ingin memfokuskan pada pengembangan media. Data penelitian ini dikumpulkan dengan metode wawancara dan kuesioner berupa angket uji ahli (uji ahli isi, uji ahli media dan uji coba produk) untuk membantu proses pengembangan serta perbaikan produk. Berdasarkan hasil angket uji ahli isi yaitu 93,75 dan ahli media yaitu 91,7 yang keduanya termasuk dalam kategori sangat sesuai. Pada hasil angket uji coba terbatas dari guru yaitu 82,7 dan dari peserta didik 86,56 yang keduanya termasuk dalam kategori sangat sesuai. Dengan demikian berdasarkan anlisis data tersebut dapat disimpulkan bahwa pengembangan media pembelajaran video untuk peserta didik sekolah dasar di Bali dapat digunakan dalam kegiatan pembelajaran bahasa Jepang.
\end{abstract}

Kata kunci: Pengembangan media, video, adobe flash, kurikulum 2013

要旨

本研究の目的はバリ島においての小学校のための 2013 年カリキュラムに基づいて、日本語学 習メディアのビデオ開発することである。教育用メディアの開発は four-D (4D) モデルを使用してい るが、メディア開発は開発段階で実行されている、開発メディアの集中に開発されてる。本研究のデ ータは、インタビュー、専門家への質疑アンケート(専門家の検閲、専門家のメディア検閲、実現可能 性検討）により収集し、それを製品開発と改善過程を支援するために使用した。専門家へのアンケー トの結果、含量とメディアの資格が「非常に適切」、総点は 93.75 と 91.7 点であった。それに、実 現可能性検討へのアンケートの結果が、教師と生徒の資格が「非常に適切」、総点は 82.7 と 86.56 点であった。したがって、これらのデータの分析により、バリ島においての小学生のための日本語学 習メディアのビデオ開発は日本語学習活動に使用できると結論付けることができます。

キーワード : メディア開発、ビデオ、アドベフラッシュ、2013 年カリキュラム。

\section{Pendahuluan}

Kurikulum terbaru yang diberlakukan di Indonesia saat ini adalah Kurikulum 2013 revisi. Kurikulum 2013 Revisi yang diberlakukan untuk SD, SMP dan SMA/SMK, dalam pelaksanaannya memfokuskan pada peningkatan keterkaitan antara Kompetensi Inti (KI) dan Kompetensi Dasar (KD). Selain itu, tujuan kurikulum 2013 revisi untuk mengembangkan bakat, minat dan potensi peserta didik agar berkarakter, kompeten dan literat (Widayat,2018). Untuk menghasilkan peserta didik yang sesuai dengan tujuan kurikulum 2013 revisi, maka proses pembelajaran juga harus sesuai dengan keterampilan abad 21 . Keterampilan abad 21 dalam kurikulum 2013 revisi meliputi PPK, Literasi, 4C, dan HOTS (Mardani,dkk., 2020).

Dalam mengimplementasikan keterampilan abad 21 tidak dapat dipisahkan dari pembelajaran berbasis Teknologi Informasi dan Komunikasi (TIK). Penenerapan pembelajaran TIK termuat didalam prinsip kurikulum 2013 yaitu yang awalnya guru sebagai satu-satunya sumber belajar sekarang menjadi belajar yang berbasis aneka sumber belajar. Hal tersebut membuktikan bahwa aneka sumber belajar tidak hanya terbatas pada buku melainkan sumber belajar berbasis TIK yang dapat berupa digital, komputer, internet, 
maupun sumber belajar lainnya. Karena kurikulum 2013 revisi berbasis aneka sumber belajar, maka untuk menerapkan kurikulum 2013 revisi dalam proses pembelajaran dibutuhkan media pembelajaran untuk menjadi sumber belajar yang sesuai dengan kurikulum 2013 revisi.

Berdasarkan hasil angket yang sudah disebarkan pada guru SD di Bali, terdapat 10 sekolah yang sudah menerapkan pembelajaran bahasa Jepang. Dari 10 sekolah terdapat 10 responden yang menyatakan sudah memiliki media pembelajaran bahasa Jepang dengan persentase sebanyak $82 \%$. Sebanyak $45 \%$ responden menyatakan memerlukan media pembelajaran bahasa Jepang sesuai dengan kurikulum 2013. Sedangkan, hasil dari wawancara yang dilakukan kepada peserta didik SD di 10 sekolah, diketahui bahwa perserta didik lebih menyukai menggunakan media pembelajaran dalam proses pembelajaran bahasa Jepang.

Melalui hasil wawancara dan angket yang telah dilakukan, maka dibutuhkan media pembelajaran yang menarik dan sesuai dengan kurikulum 2013 revisi untuk jenjang SD di Bali. Sehingga untuk mengatasi permasalahan tersebut yaitu dengan menggunakan media pembelajaran video bahasa Jepang berbasis adobe flash. Media pembelajaran dalam proses pembelajaran digunakan untuk menyampaikan isi materi pembelajaran yang diharapkan mampu memotivasi peserta didik untuk belajar. Selain itu, media menjadi salah satu bagian penting untuk mencapai tujuan pembelajaran yang diinginkan dalam kegiatan pembelajaran. Media pembelajaran video dipilih karena sesuai dengan karakteristik peserta didik yang mudah bosan, aktif, serta masih suka bermain. Maka, media pembelajaran video ini dikembangkan untuk dapat menarik perhatian peserta didik, serta lebih efektif dan lebih efisien dalam proses pembelajaran. Selain itu, media pembelajaran video juga dipilih karena belum tersedianya media pembelajaran bahasa Jepang di SD. Selain itu, video dalam pengembangan ini dibuat dengan berbasis adobe flash. Adobe Flash merupakan sebuah software yang digunakan untuk membuat games, aplikasi, dan konten-konten lainnya sesuai dengan keinginan pengguna

Terkait hal tersebut, terdapat penelitian sejenis yang sudah dikembangkan yaitu oleh Dewi dkk (2017) dan Setiani (2015). Penelitian yang dilakukan oleh Dewi dkk adalah pengembangan aplikasi berbasis adobe flash. Media yang dikembangkan bertujuan untuk melatih kemampuan mahasiswa dalam bahasa Jepang level N4 khususnya elemen moji-goi (huruf dan kosakata) di Jurusan Pendidikan Bahasa Jepang UNDIKSHA. Dalam penelitan oleh Dewi dkk dikatakan bahwa aplikasi dengan berbasis adobe flash dapat membantu mahasiswa dalam melatih kemampuan bahasa Jepang untuk level N4. Sedangkan, penelitian yang dilakukan oleh Setiani (2015) adalah pengembangan aplikasi adobe flash yang bertujuan untuk dapat membantu peserta didik dalam proses penyerapan materi menjadi lebih maksimal karena dalam penggunaan aplikasi tersebut melibatkan indera penglihatan serta indera pendengaran peserta didik. Dalam penelitian Setiani dikatakan bahwa adobe flash adalah media pembelajaran interaktif untuk meningkatkan kemampuan peserta didik dalam mengapresiasi teks cerita pendek bahasa Indonesia.

Berdasarkan latar belakang tersebut, maka masalah yang hendak dijawab dalam penelitian ini adalah "Bagaimanakah pengembangan media pembelajaran video bahasa jepang berbasis adobe flash untuk Sekolah Dasar di Bali?" Media ini dibuat karena diperlukan oleh guru pengajar dan peserta didik SD di Bali. Selain itu, media yang dikembangkan akan menjadi penunjang proses pembelajaran bahasa Jepang yang sesuai dengan kurikulum 2013 revisi untuk SD di Bali.

\section{Metode}

\section{Model Penelitian Pengembangan}

Pengembangan media pembelajaran dalam penelitian ini menggunakan model four- $D$ (4D) dari Thiagarajan (dalam Wardoyo dan Ma'arif, 2015) terdapat empat tahapan yaitu: Define (pendefinisian), Design (perencanaan), Develop (pengembangan), Disseminate (penyebaran). Namun, pada pengembangan media pembelajaran video bahasa Jepang berbasis adobe flash ini dilakukan sampai tahap develop (pengembangan). Pada tahap keempat yaitu Disseminate tidak dilakukan dikarenakan keterbatasan waktu penelitian. 


\section{Prosedur Penelitian Pengembangan}

Dalam penelitian pengembangan media pembelajaran dengan menggunakan model Four-D (4D). Menurut Thiagarajan, model ini terdiri dari 4 tahapan (dalam Mulyatiningsih, 2016) sebagai berikut :

\section{Tahap 1 : Define}

Tahap define (pendefinisian) merupakan tahap analisis kebutuhan. Dalam penelitian ini, tahap define dilakukan dengan wawancara terstruktur kepada peserta didik SD di Bali yaitu sesuai dengan jenjang kelas yang sudah mendapatkan mata pelajaran bahasa Jepang, serta dilakukan penyebaran angket untuk guru SD di Bali yang mengampu mata pelajaran bahasa Jepang. Berdasarkan hasil wawancara kepada peserta didik diketahui bahwa dalam proses pembelajaran bahasa Jepang peserta didik menyukai menggunakan media, selain itu berdasarkan hasil angket yang telah diberikan dikatakan bahwa materi yang diajarkan pada peserta didik masih pada materi mengenai kosakata dasar bahasa Jepang. Wawancara dan penyebaran angket dilakukan untuk menganalisis kebutuhan dari media yang akan dikembangkan.

\section{Tahap 2 : Design}

Dalam tahap design (perancangan) yaitu membuat produk awal (prototype) atau rancangan produk yang akan dikembangkan. Racangan yang dilakukan adalah menyusunan tes kriteria media untuk disesuaikan dengan proses pembelajaran kurikulum 2013 dan disesuaikan dengan perkembangan kognitif anak SD. Selain itu memilih media dan penyajian media untuk membuat media yang menarik bagi peserta didik SD, serta membuat konsep media dan membuat daftar kosakata ataupun kalimat yang akan terdapat dalam media.

\section{Tahap 3 : Develop}

Tahap Develop (tahap pengembangan) terdapat dua kegiatan yaitu : expert appraisal dan developmental testing. Expert appraisal merupakan teknik untuk memvalidasi atau menilai kelayakan rancangan produk. Dalam kegiatan ini dilakukan evaluasi oleh ahli dalam bidangnya. Saran-saran yang diberikan digunakan untuk memperbaiki materi dan rancangan pembelajaran yang telah disusun. Developmental testing merupakan kegiatan uji coba rancangan produk pada sasaran subjek yang sesungguhnya.

Kemudian setelah prosedur penelitian, dilanjutkan pada tahap pengumpulan data dengan metode kuesioner dengan menggunakan angket uji ahli (uji ahli isi, media, dan uji coba produk) dan setelah dilakukan pengumpulan data dilanjutkan dengan penyempurnaan produk berdasarkan komentar dan saran yang didapatkan dari tahap uji ahli.

\section{Uji Coba Produk}

\section{Desain Uji Coba}

Pada desain uji coba, dalam mengembangkan media pembelajaran video bahasa Jepang berbasis adobe flash bagi anak SD di Bali ini menggunakan uji ahli. Uji ahli dimaksudkan untuk memperoleh saran, tanggapan dan pendapat terhadap media pembelajaran yang dikembangkan. Selain itu dilakukan uji coba terbatas di lapangan untuk mengetahui respon guru dan peserta didik terhadap media.

\section{Subjek Uji Coba}

Subjek uji coba pada penelitian pengembangan ini adalah peserta didik SD di Bali yang mempelajari bahasa Jepang. Uji coba ini dilakukan untuk mengetahui reaksi peserta didik terhadap media pembelajaran yang dikembangkan

\section{Jenis Data}

Jenis data penelitian ini menggunakan angket dan wawancara, data yang dikumpulkan merupakan anlisis kebutuhan dan masalah yang terdapat di dalam pembelajaran bahasa Jepang dengan standar proses kurikulum 2013 di sekolah dasar di Bali.

4. Metode dan Instrumen Pengumpulan Data

Penelitian ini menggunakan dua instrumen penelitian yang digunakan untuk mengumpulkan dan menganalisis data, yaitu wawancara dan angket. Wawancara yang dilakukan dalam penelitian ini yaitu wawancara dengan peserta didik SD di Bali sesuai dengan jenjang kelas yang sudah mendapatkan mata pelajaran bahasa Jepang untuk 
menganalisis kebutuhan terkait media yang akan dikembangkan. Angket digunakan untuk menganalisis kebutuhan yaitu dengan memberikan angket kepada guru SD di Bali yang mengampu mata pelajaran bahasa Jepang. Serta angket juga digunakan untuk melakukan uji ahli isi, media serta uji coba produk.

Metode dan Teknik Analisis Data

Hasil dari uji ahli dan uji coba terhadap guru dihitung menggunakan rumus sebagai berikut.

Tabel 1. Kriteria Tingkat Validitas Perangkat Pembelajaran

\begin{tabular}{|c|c|}
\hline SKOR & KRITERIA \\
\hline $76<\mathrm{SR} \leq 100$ & Sangat Sesuai (SS) \\
\hline $51<\mathrm{SR} \leq 75$ & Sesuai $(\mathrm{S})$ \\
\hline $26<\mathrm{SR} \leq 50$ & Kurang Sesuai (KS) \\
\hline $0<\mathrm{SR} \leq 25$ & Tidak Sesuai (TS) \\
\hline
\end{tabular}

Kirna, 2010

Rumus :

$S R=\frac{\text { Jumlah skor dalam semua item }}{\text { Jumlah skor maksimal }} \times 100$

Keterangan :

$\mathrm{SR}=$ Skor rata-rata berdasarkan hasil validasi

Dalam penelitian ini, skor rata-rata maksimal yang harus dicapai yaitu interval $51<\mathrm{SR} \leq 75$. Dengan demikian perangkat pembelajaran yang dikembangkan dapat dinyatakan layak digunakan.

Adapun hasil angket uji coba yang telah diberikan kepada peserta didik dihitung dengan rumus sebagai berikut.

$$
x=\sum x-n
$$

Keterangan :

$\mathrm{X}=$ Jumlah responden yang menyatakan setuju

$\mathrm{n}=$ Jumlah responden yang menyatakan tidak setuju

$\sum \mathrm{x}=$ Total seluruh jumlah responden

Kemudian jumlah responden yang menyatakan setuju sudah diperoleh, maka kembali dihitung untuk mmendapatkan hasil presentase kelayakan media. Dengan rumus sebagai berikut.

Hasil $=\frac{\text { Jumlah total responden setuju }}{\text { Jumlah indikator }} \times 100$

Tabel 2. Kriteria Kelayakan Media

\begin{tabular}{|c|c|}
\hline Skor dalam persen & Kategori Kelayakan \\
\hline$<21 \%$ & Sangat Tidak Layak \\
\hline $21-40 \%$ & Tidak Layak \\
\hline $41-60 \%$ & Cukup Layak \\
\hline $61-80 \%$ & Layak \\
\hline $81-100 \%$ & Sangat Layak \\
\hline
\end{tabular}

Arikunto, 2006

Dalam penelitian ini, skor rata-rata maksimal yang harus dicapai yaitu interval 81$100 \%$. Dengan demikian perangkat pembelajaran yang dikembangkan dapat dinyatakan layak digunakan. 


\section{Hasil dan Pembahasan}

\section{Penyajian Data Uji Coba}

Media yang dikembangkan dalam penelitian ini adalah video dengan karakter animasi yang memuat tentang kosakata maupun ungkapan dasar bahasa Jepang untuk anak SD di Bali. Media video yang dikembangkan terdiri dari 10 bab yang meliputi materi : (1) salam sapaan (aisatsu); (2) perkenalan diri (jikoshoukal); (3) angka (suuji); (4) warna (iro); (5) nama hari (youbı); (6) anggota badan (karada); (7) keluarga (watashi no kazoku); (8) keluarga orang lain (Sita san no kazoku); (9) angka bagian 2 (suuji ni); dan (10) Usia (nenrel). Selain itu, animasi didalam video dibuat mirip dengan benda ataupun keadaan yang konkret di kehidupan sehari-hari, agar peserta didik dapat mampu memahami materi terkait yang dipaparkan serta mampu berpikir secara kritis sesuai dengan tuntutan kurikulum 2013 revisi. Dengan video tersebut peserta didik diharapkan mampu berpikir secara kritis terhadap ungkapan atau kosakata dan materi bahasa Jepang yang disampaikan. Selain itu, dengan proses pembelajaran menggunakan video akan lebih menyenangkan serta peserta didik termotivasi dalam pembelajaran bahasa Jepang.

Video ini digunakan bagi peserta didik SD di Bali yang menerapkan pembelajaran bahasa Jepang. Pengajar dapat menggunakan media ini dalam proses pembelajaran ketika awal pembelajaran maupun akhir pembelajaran, ataupun ketika peserta didik mulai bosan dalam pembelajaran yang berlangsung. Video ini terdiri dari 10 bab yang disusun sesuai dengan analisis kebutuhan melalui angket dan wawancara. Video ini dibuat dengan karakter animasi yang diikuti dengan suara dalam bahasa Jepang yang direkam oleh seorang native speaker. Selain itu, kosakata yang digunakan dalam video masih tergolong kosakata dasar bahasa Jepang yang sesuai dengan jenjang anak SD. Selain itu llustrasi yang digunakan merupakan ilustrasi yang dibuat manual menggunakan adobe flash. Adapun struktur dari video yang telah dibuat yaitu sebagai berikut :

1. Bab 1 : Salam sapaan (aisatsu)

Bab 1 menyajikan bermacam-macam kosakata tentang salam sapaan dalam bahasa Jepang.
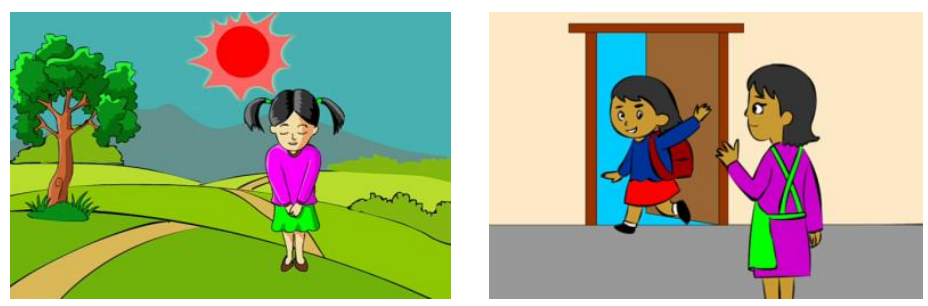

Gambar 1. Ilustrasi Bab 1

2. Bab 2 : Perkenalan diri (jikoshoukai)

Bab 2 menyajikan kalimat sederhana untuk memperkenalkan diri dalam bahasa Jepang.
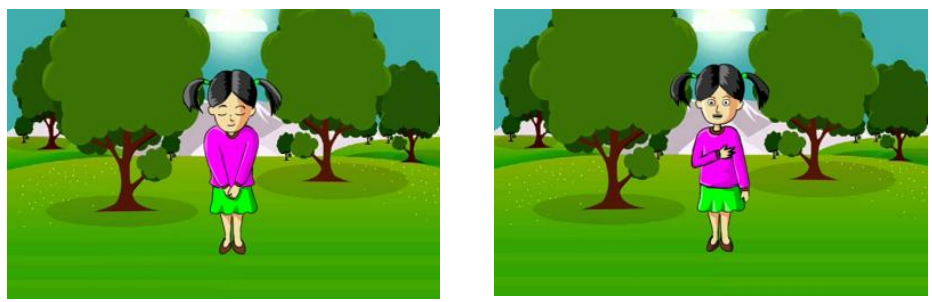

Gambar 2. Ilustrasi Bab 2

3. Bab 3 : Angka (suuji)

Bab 3 perkenalan kosakata angka yaitu dari angka 1 sampai 20. 


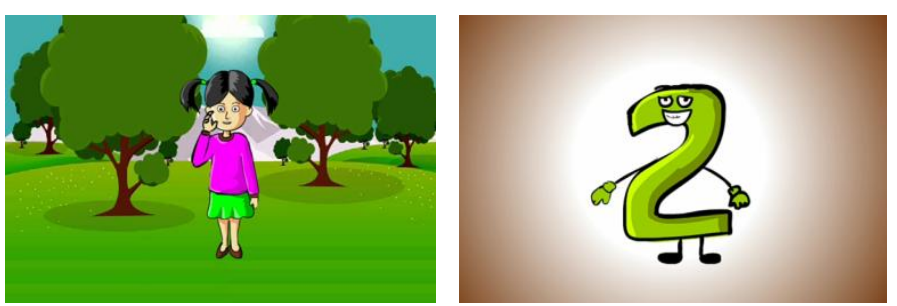

Gambar 3. Ilustrasi Bab 3

4. Bab 4 : Warna (iro)

Bab 4 menyajikan kosakata warna dalam bahasa Jepang.
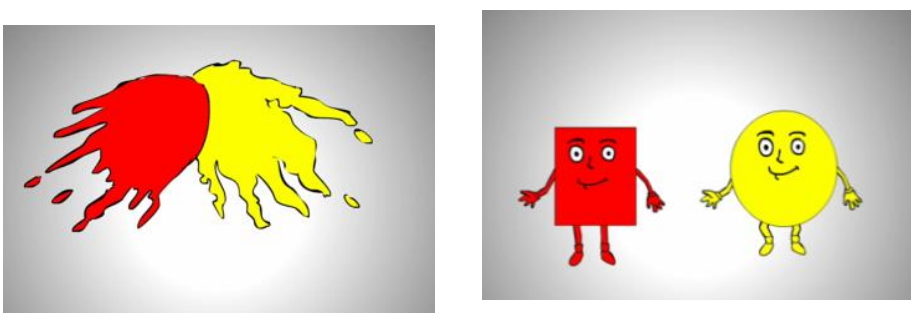

Gambar 4. Ilustrasi Bab 4

5. Bab 5 : Nama hari (youbi)

Bab 5 menyajikan kosakata nama-nama hari dalam bahasa Jepang.
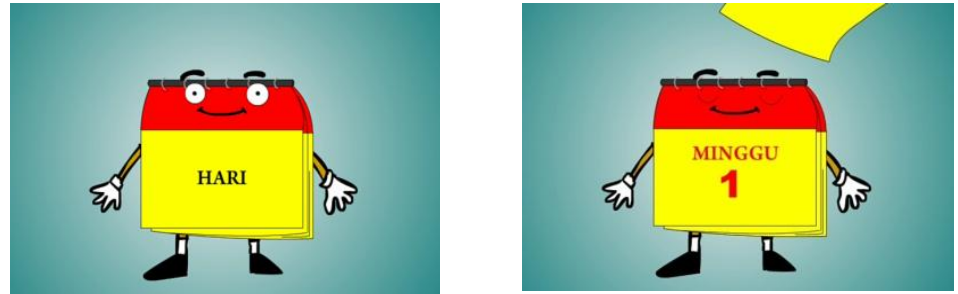

Gambar 5. Ilustrasi Bab 5

6. Bab 6 : Anggota badan (karada)

Bab 6 menyajikan kosakata nama-nama anggota badan dalam bahasa Jepang.
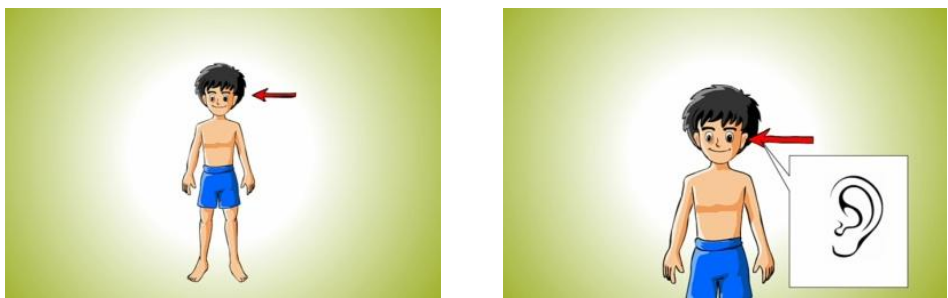

Gambar 6. Ilustrasi Bab 6

7. Bab 7 : Keluarga (watashi nokazoku)

Bab 7 menyajikan kosakata untuk menyebutkan anggota keluarga (diri sendiri) dalam bahasa Jepang.
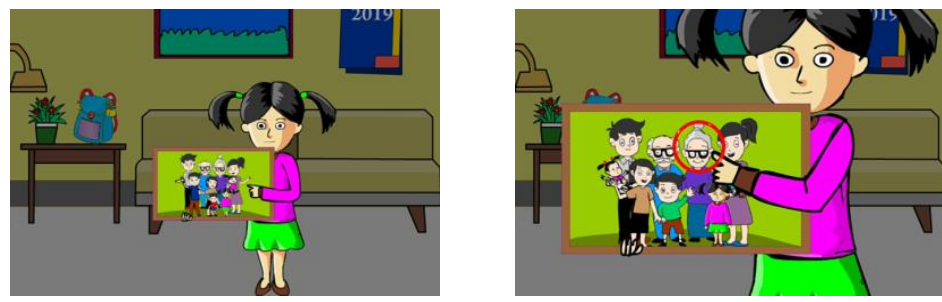

Gambar 7. Ilustrasi Bab 7

8. Bab 8 : Keluarga orang lain (Sita san no kazoku)

Bab 8 menyajikan kosakata untuk menyebutkan anggota keluarga orang lain dalam bahasa Jepang. 

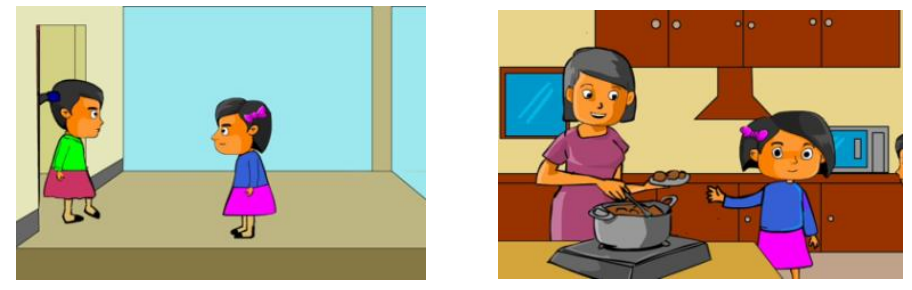

Gambar 8. Ilustrasi Bab 8

9. Bab 9: Angka bagian 2 (suuji ni)

Pada bab 9 perkenalan kosakata angka yaitu dari angka 21 sampai 100.
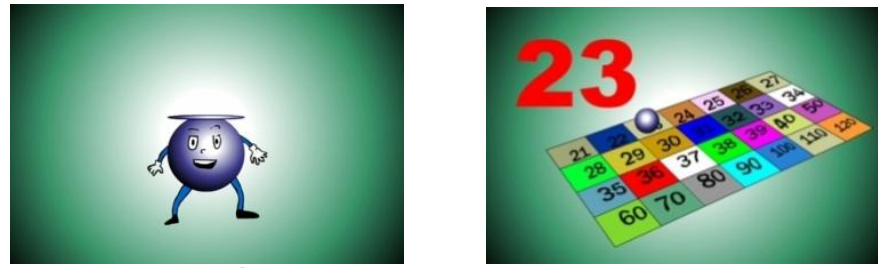

Gambar 9. Ilustrasi Bab 9

10. Bab 10 : Usia (nenrei)

Bab 10 yang menyajikan penyebutan usia dalam bahasa Jepang
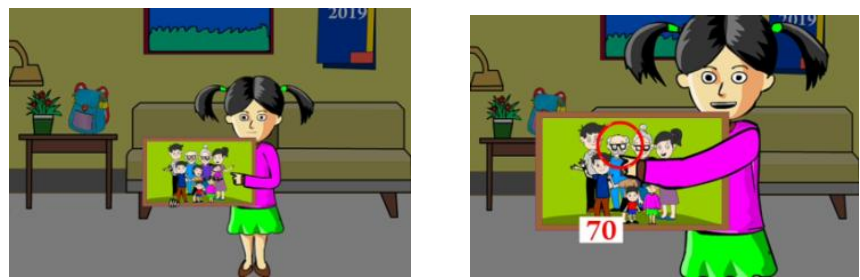

Gambar 10. Ilustrasi Bab 10

Pada media pembelajaran video yang dikembangkan juga terdapat latihan-latihan serta kalimat perintah agar peserta didik dapat lebih aktif dalam mengikuti pembelajaran yang berlangsung melalui media video.

Hasil Analisis Angket Uji Ahli

Sebelum menghasilkan media pembelajaran yang layak digunakan, maka perlu dilakukan tahap uji ahli agar menghasilkan produk yang berkualitas dan sesuai dengan kebutuhan sasaran. Tahap uji ahli dilakukan dengan memberikan angket kepada para ahli yang memuat beberapa pernyataan mengenai media pembelajaran yang akan dikembangkan agar dapat dinilai isi materi dan media pembelajarannya. Selain itu, angket diberikan kepada guru dan peserta didik untuk mengetahui kelayakan, serta respon terhadap media yang dikembangkan. Penilaian angket menggunakan penilaian skala 4 yakni Sangat Setuju (SS) $=4$, Setuju (S) $=3$, Tidak Setuju $(T S)=2$, Sangat Tidak Setuju $($ STS $)=1$.

Angket uji ahli isi diberikan kepada Dosen Program Studi Pendidikan Bahasa Jepang, Universitas Pendidikan Ganesha. Angket ini diberikan pada tanggal 30 Januari 2020. Persentase total skor untuk uji ahli isi adalah 93,75 dengan kategori sangat sesuai.

Angket uji ahli media diberikan kepada Dosen Program Studi Desain Komunikasi Visual, Universitas Pendidikan Ganesha. Angket ini diberikan pada tanggal 21 September 2019. Persentase total skor untuk uji ahli desain adalah 91,7 dengan kategori sangat sesuai.

Angket uji coba produk diberikan kepada salah satu pengajar bahasa Jepang SD di Bali yaitu SD Mutiara Singaraja. Angket ini diberikan pada tanggal 7 Februari 2020. Persentase total skor uji ahli kelayakan adalah 82,7 dengan kategori sangat sesuai. Selain itu, angket uji coba juga diberikan kepada kepada 36 peserta didik SD Mutiara Singaraja yang mempelajari bahasa Jepang. Angket ini diberikan pada tangga 16 Maret 2020. Persentase total skor uji ahli kelayakan adalah 86,56\% dengan kategori sangat layak. 


\section{Hasil Analisis Data}

Untuk menghasilkan produk yang layak digunakan, maka dilakukan tahap uji ahli terlebih dahulu untuk dapat menghasilkan produk yang berkualitas dan sesuai dengan kebutuhan responden. Media pembelajaran video yang dihasilkan sudah melalui beberapa tahapan perbaikan dengan memperbaiki penggunaan bahasa Jepang dan media pembelajaran agar sesuai serta menjadi lebih menarik. Tahap uji ahli dilakukan oleh 2 orang penguji ahli. Penguji ahli isi merupakan dosen Program Studi Pendidikan Bahasa Jepang dan penguji ahli media merupakan dosen Progam Studi Desain Komunikasi Visual (DKV) di Universitas Pendidikan Ganesha.

Berdasarkan penilaian yang diberikan uji ahli isi terhadap media yang dikembangkan yaitu cakupan materi, keseuaian dan ketepatan gambar pada media dianggap sudah sesuai, karena materi yang terdapat pada media pembelajaran video berbasis adobe flash sudah sesuai dengan tahap pembelajaran bahasa Jepang yaitu tahap pembelajaran dasar yang memaparkan kosakata dan kalimat sederhana dalam bahasa Jepang. Penyajian media pembelajaran video adobe flash bersifat komunikatif dan interaktif yang dianggap sudah sesuai, karena dalam media terdapat kalimat perintah serta pertanyaan yang mampu memotivasi peserta didik untuk aktif dalam pembelajaran. Kemudian dalam komponen penyaji sudah sesuai dengan saran perbaikan berupa : memberikan cover pada setiap bab pada media pembelajaran video, untuk mempermudah pengguna mengetahui materi dalam media. Selain itu, penguji memberi saran untuk menambahkan latihan singkat pada materi dalam media pembelajaran video.

Berdasarkan penilaian yang diberikan uji ahli media terhadap media yang dikembangkan yaitu untuk tampilan media dianggap sudah sesuai dengan saran perbaikan berupa: penyempurnaan pada detail objek seperti gambar mulut, warna ungu, dan sikap ojigi yang perlu diperbaiki. Kemudian untuk peniilaian isi dalam media, efesiensi media menunjukan bahwa media sudah sesuai untuk membantu dalam pembelajaran bahasa Jepang tingkat SD dan media sudah sesuai untuk membantu pemahaman peserta didik terhadap pembelajaran bahasa Jepang. Selain itu, pada penilaian kualitas media yaitu media sudah sesuai untuk menarik peserta didik sehingga memotivasi untuk belajar, serta suara dalam media yang sudah jelas dan sesuai

Penilaian uji coba terbatas yang dilakukan oleh salah satu pengajar bahasa Jepang SD di Bali yaitu SD Mutiara Singaraja, serta 36 peserta didik SD Mutiara Singaraja. Berdasarkan penilaian uji coba terbatas terhadap media yang dikembangkan yaitu kosakata yang digunakan dalam video sudah sesuai dengan materi tingkat sekolah dasar serta penyajian gambar atau video animasi sangat menarik, interaktif dan komunikatif, sehingga mampu meningkatkan pemahaman peserta didik terhadap pembelajaran bahasa Jepang. Selain itu, berdasarkan penilaian dari peserta didik menyatakan bahwa peserta didik menyukai media pembelajaran dalam belajar bahasa Jepang, mudah memahami pembelajaran dengan media, dapat meningkatkan minat peserta didik, serta peserta didik menjadi menyukai pembelajaran bahasa Jepang dengan menggunakan media pembelajaran karena menarik.

\section{Revisi Produk}

Setelah dilakukan uji ahli isi dan desain, harus dilakukan revisi kembali untuk mendapatkan produk akhir. Berikut adalah kajian produk yang telah direvisi berdasarkan saran dari uji ahli.

\section{Tampilan Awal}

Berdasarkan saran dari uji ahli Isi, dalam media video perlu adanya tampilan awal berupa judul materi untuk mempermudah dalam mengenali materi yang disampaikan dalam media video. Pada tampilan media pembelajaran video sebelumnya terdapat animasi yang muncul dan juga terdapat background pepohonan. Namun megalami perbaikan atas saran uji ahli isi, maka tampilan awal berupa judul materi pada media pembelajaran video. 


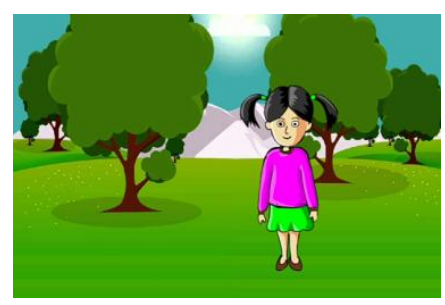

Sebelum Revisi

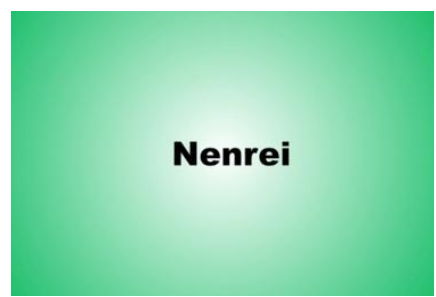

Sesudah Revisi

Gambar 11. Revisi Tampilan Awal

\section{Menambahkan latihan pada media}

Pada awalnya dalam media pembelajaran video hanya terdapat penjelasan kosakata bahasa Jepang. Berdasarkan saran dari uji ahli isi, dalam media video perlu adanya latihanlatihan singkat. Maka, pada beberapa materi media pembelajaran yang dikembangkan terdapat latihan-latihan singkat berupa menebak kosakata dalam bahasa Jepang.

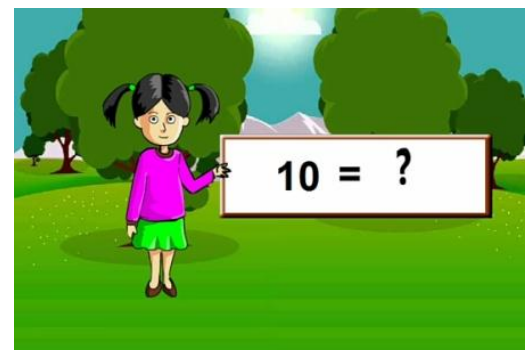

Gambar 12. Peraikan dalam menambahkan latihan pada media

3. Perbaikan Pada Gambar "Mulut"

Pada bab 6 yaitu tentang anggota tubuh, pada bagian menyebutkan mulut gambar yang ditampilkan mulut yang terdapat gigi dan lidah. Berdasarkan saran uji ahli desain.Maka, gambar mulut perlu dirubah karena gambar tersebut membuat kesan yang ambigu. Hal ini menurut uji ahli dapat menimbulkan pemahaman yang salah, karena saat menyebutkan kosakata mulut dalam gambar yang ditampilkan juga terdapat lidah dan gigi.

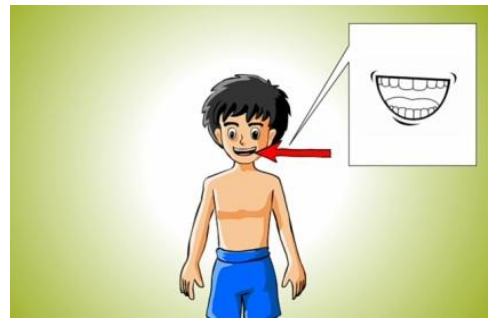

Sebelum Revisi

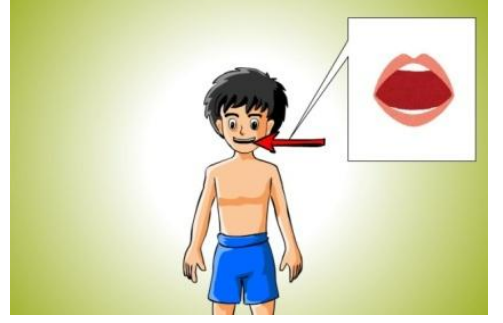

Sesudah Revisi

4. Perbaikan pada warna "Ungu"

Gambar 13 Revisi Pada Gambar "Mulut"

Pada awalnya dalam bab 4 yaitu warna. Terdapat warna ungu yang ditampilkan dalam media. Namun berdasarkan saran uji ahli desain, warna ungu yang ditampilkan masih masuk kedalam kategori warna ungu muda. Maka perlu ada perbaikan yaitu mengubah warna ungu muda menjadi warna ungu dasar atau gelap.

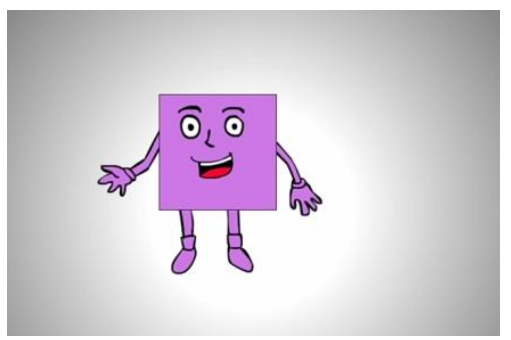

Sebelum Revisi

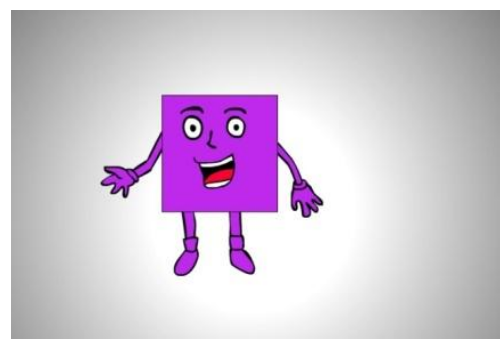

Sesudah Revisi

Gambar 14. Perbaikan pada warna "Ungu 


\section{Perbaikan sikap ojigi pada media}

Dalam media video, untuk mengawali video terdapat animasi yang melakukan ojigi. Tentunya, ojigi yang dilakukan oleh animasi haruslan benar. Namun, pada media video terdapat kesalahan animasi dalam melakukan ojigi. Maka, berdasarkan saran uji ahli desain perlu adanya perbaikan yang sesuai. Karena itu, ojigi yang dilakukan harus sesuai antara ojigi perempuan dan ojigi laki-laki.

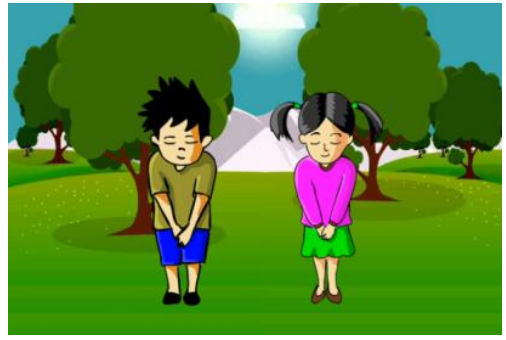

Sebelum Revisi

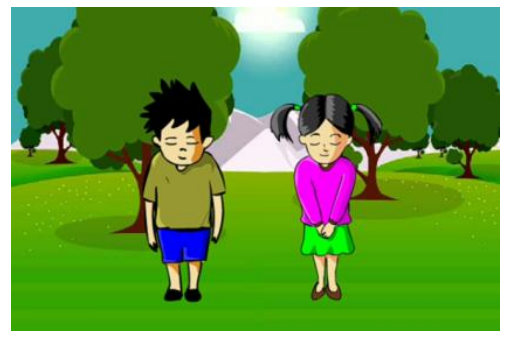

Sesudah Revisi

Gambar 15. Perbaikan sikap ojigi pada media

\section{Pembahasan Hasil Penelitian}

Berdasarkan latar belakang yang telah dipaparkan pada bab I penelitian ini dilakukan karena kurang ketersediannya media pembelajaran bahasa Jepang yang sesuai kurikulum 2013 revisi. Hal tersebut dapat dilihat dari hasil angket yang telah disebarkan kepada guru bahasa Jepang SD di Bali, diperoleh hasil bahwa terdapat sekolah yang tidak menggunakan media pembelajaran dalam proses pembelajaran bahasa Jepang, selain itu dari 11 responden 10 yang menyatakan perlu dibuatkan media pembelajaran berbasis kurikulum 2013 revisi. Sehingga dari permasalahan tersebut dibutuhkan media pembelajaran yang sesuai dengan tuntutan kurikulum 2013 revisi.

Oleh karena itu, dikembangkanlah media pembelajaran video berbasis adobe flash karena dapat menarik perhatian peserta didik, efektif dan lebih efisien dalam proses pembelajaran. Media pembelajaran menjadi salah satu faktor penting dalam proses pembelajaran karena media pembelajaran menjadi alat bantu yang digunakan oleh guru untuk menyampaikan materi pembelajaran. Oleh karena itu, keberadaan media pembelajaran sebagai alat bantu dalam proses pembelajaran bahasa Jepang di Sekolah Dasar diperlukan. Selain itu berdasarkan hasil wawancara kepada peserta didik, menyatakan bahwa media pembelajaran yang digunakan masih dalam bentuk visual seperti kartu gambar, papan tulis, kartu huruf, lagu dan buku. Jadi, dapat dikatakan bahwa perlu adanya media pembelajaran berupa video untuk meningkatkan kemampuan peserta didik dari mendengar, melihat serta mencoba untuk berbicara sesuai arahan yang terdapat pada video.

Media pembelajaran video berbasis adobe flash ini dirancang dengan mempertimbangkan hal tersebut, maka media dibuat dengan suara yang lucu agar peserta didik tertarik terhadap suaranya. Selain itu, media dibuat dengan gambar -gambar yang sesuai dengan hal atau benda yang berada disekitar peserta didik dalam kehidupan seharihari, hal ini dapat membantu peserta didik untuk mengaitkan suara serta gambar dalam media. Dalam media pembelajaran video berbasis adobe flash ini terdapat kalimat perintah yang meminta peserta didik untuk mengulang kosakata dalam media, serta terdapat latihan menebak kosakata bahasa Jepang yang benar. Hal tersebut membantu peserta didik untuk lebih aktif serta membantu dalam hal mengingat pembelajaran bahasa Jepang yang telah dipelajari melalui media.

Media pembelajaran video berbasis adobe flash ini juga dirancang sesuai dengan tuntutan kurikulum yang berlaku saat ini yaitu kurikulum 2013 revisi. Pada media yang dikembangkan memuat pembelajaran HOTS (Higher Order of Thingking Skill). Materi yang disampaikan dalam media video sudah bertahap sesuai dengan tingkatan HOTS yang meliputi mengetahui, memahami, mengaplikasi, serta menganalisis. Pada media sudah sesuai dengan pembelajaran HOTS dimulai pada tingkat pertama yaitu mengetahui, dalam 
media pembelajaran video berbasis adobe flash menyampaikan kosakata bahasa Jepang dan mengulangnya kembali untuk meningkatkan kemampuan mengingat peserta didik. Contohnya pada materi angka (Suuji), pada media video terdapat ilustrasi yang menampilkan angka yang melompat agar dapat menarik perhatian peserta didik serta terdapat pegulangan kosakata angka dalam bahasa Jepang yang dapat meningkatkan kemampuan mengingat peserta didik. Pada tingkat kedua yaitu memahami, dalam media pembelajaran video berbasis adobe flash ini peserta didik dituntut untuk memahami keterkaitan antara gambar serta pengucapan kosakata dalam bahasa Jepang. Contohnya pada materi salam sapaan (aisatsu) yaitu terdapat ilustrasi pada video yang menampilkan animasi matahari yang bergerak dari pagi hingga malam, sehingga peserta didik diharapkan mampu memahami makna dari pergerakan matahari tersebut yang berkaitan dengan salam sapaan dalam bahasa Jepang.

Pada tingkat ketiga yaitu mengaplikasikan, dalam media pembelajaran video berbasis adobe flash ini peserta didik dituntun untuk bisa mengaplikasikan atau menerapkan materi yang sudah disampaikan pada media. Contohnya pada materi anggota badan atau nama-nama hari, dalam media setelah memperkenalkan kosakata terdapat latihan pengucapan kosakata dengan melihat animasi atau gambar yang muncul secara acak. Hal tersebut menuntut peserta didik untuk mengingat kosakata yang disampaikan sebelumnya, serta kemudian menjawab pertanyaan - pertanyaan yang menuntut peserta didik untuk berbicara dengan bahasa Jepang. Selain terdapat latihan, pertanyaan, dalam media juga terdapat kalimat perintah dalam bahasa Jepang yang menuntut peserta didik untuk dapat berbicara dalam bahasa Jepang. Latihan, pertanyaan serta kalimat perintah yang terdapat pada media dapat membantu peserta didik untuk lebih aktif dalam pembelajaran bahasa Jepang. Pada tingkat keempat yaitu menganalisis, dalam media pembelajaran video berbasis adobe flash ini peserta didik dituntun untuk memiliki kemampuan menganalisis. Contohnya pada materi umur (Nenrel) yaitu terdapat animasi yang memperkenalkan anggota keluarganya beserta dengan umur dari masing-masing anggota keluarganya. Pada penyampaian umur dalam bahasa Jepang terdapat pola kalimat yang digunakan, sehingga peserta didik dituntut untuk berpikir kritis terhadap keterkaitan antara konsep pola kalimat bahasa Jepang dengan gambar yang ditampilkan pada media. Selain itu, dalam media video yang dikembangkan beberapa media tidak terdapat bahasa Indonesia dalam bentuk lisan maupun tulisan, namun menggunakan pengucapan dalam bahasa Jepang dan gambar yang disesuikan dengan materi. Hal tersebut menuntut peserta didik untuk menyimak dengan baik materi yang disampikan dalam media, serta menuntut peserta didik berpikir kritis terhadap media yang disampikan. Dengan demikaian media pembelajaran video berbasis adobe flash ini sudah sesuai dengan kurikulum 2013 yaitu HOTS (Higher Order of Thingking Skill).

Pengembangan media pembelajaran video berbasis adobe flash ini telah disusun berdasarkan tahap pengembangan four- $D$ yang terdiri dari define (pendefinisian/analisis) yaitu dengan melakukan penyebaran angket serta wawancara terhadap kurikulum serta media yang digunakan dalam proses pembelajaran bahasa Jepang. Pada tahap design (perancangan) yaitu melakukan perancangan produk yang meliputi format media, isi materi, dan design. Pada tahap ketiga Develop (pengembangan) yaitu melakukan uji ahli isi dan uji ahli media terhadap produk yang dikembangkan. Berdasarkan hasil angket untuk tahap validasi uji ahli isi dan uji ahli media, hasil penilaian menunjukkan bahwa tingkat validasi uji ahli isi dan uji ahli desain berada pada kualifikasi sangat sesuai. Sehingga dapat disimpulkan bahwa media pembelajaran video berbasis adobe flash ini sudah layak dan sesuai. Tahap terakhir yaitu Disseminate (penyebaran), namun pada penelitian pengembangan ini hanya sampai pada tahap Develop (pengembangan) karena keterbatasan waktu penelitian.

Media pembelajaran video berbasis adobe flash ini sudah dinyatakan layak oleh ahli dalam hal isi media serta penyajian media. Media yang dikembangkan sudah dinyatakan layak, karena berdasarkan skor rata-rata dari hasil angket uji ahli isi yaitu 93,75 dan ahli media yaitu 91,7 yang keduanya termasuk dalam kategori sangat sesuai. Selain, itu uji coba terbatas yang dilakukan kepada guru serta peserta didik dengan menyebarkan angket mendapat skor rata-rata dari guru yaitu 82,7 dan dari peserta didik 86,56 yang keduanya juga termasuk dalam kategori sangat sesuai. Selain itu, terdapat tanggapan dari guru SD 
Mutiara Singaraja yang mengungkapkan bahwa media sangat menarik, interaktif dan komunikatif sehingga mampu meningkatkan pemahaman peserta didik terhadap pembelajaran bahasa Jepang. berikut.

Adapun kelebihan media pembelajaran video berbasis adobe flash ini sebagai

1. Media pembelajaran video berbasis adobe flash ini dirancang sesuai tuntutan kurikulum 2013 revisi yaitu menuntut peserta didik untuk birpikir tingkat tinggi (HOTS).

2. Media pembelajaran video berbasis adobe flash ini menyajikan kosakata bahasa Jepang sederhana dengan animasi yang dapat bergerak, serta suara animasi yang lucu.

3. Terdapat latihan soal terkait kosakata bahasa Jepang pada beberapa bab video. Selain itu, pada media terdapat kalimat perintah yang menuntut peserta didik untuk aktif dan mengikuti arahan dari animasi pada media.

Demikianlah pentingnya media pembelajaran video berbasis adobe flash ini dikembangkan. Sehingga dapat digunakan oleh guru dan peserta didik sebagai alat bantu dalam pembelajaran bahasa Jepang sekolah dasar dalam meningkatkan keterampilan berbahasa Jepang.

\section{Simpulan dan Saran}

Simpulan yang dapat dirumuskan yaitu media pembalajaran video bahasa Jepang berbasis adobe flash ini sudah layak digunakan dalam proses pembelajaran, serta sudah sesuai dengan kurikulum 2013 revisi dan karakteristik anak SD. Pada media terdapat latihan kosakata serta perintah yang membantu peserta didik untuk aktif dan berpikir kritis, serta meningkatkan kemampuan peserta didik dalam pembelajaran bahasa Jepang.

Media ini terdiri dari 10 bab yang disusun sesuai dengan analisis kebutuhan melalui angket. Serta pada beberapa bab terdapat latihan soal yang membantu guru mengetahui pemahaman peserta didik terhadap materi, sekaligus membantu peserta didik untuk berpikir kritis.

Berdasarkan penilaian uji ahli serta uji coba, media pembelajaran adobe flash dinilai sudah sangat sesuai. Skor rata-rata dari hasil angket uji ahli isi yaitu 93,75 dan ahli media yaitu 91,7 . Selain itu, uji coba terbatas yang dilakukan mendapat skor rata-rata dari guru yaitu 82,7 dan dari peserta didik 86,56. Dengan demikian media pembelajaran video berbasis adobe flash yang dikembangkan layak untuk digunakan dalam pembelajaran bahasa Jepang sekolah dasar di Bali.

Saran yang dapat disampaikan kepada peneliti lainnya yaitu disarankan untuk menyusun media pembelajaran bahasa Jepang untuk sekolah dasar yang lain, serta sesuai dengan kurikulum dan silabus. Media pembelajaran bahasa Jepang untuk peserta didik sekolah dasar disarankan dapat menyajikan cakupan materi yang lebih luas, menyajikan media yang lebih menarik dan inovatif. Selain itu, peneliti lainnya disarankan untuk menyusun media pembelajaran yang dapat menyajikan latihan-latihan maupun pertanyanpertanyaan yang lebih bervariasi dalam membantu peserta didik untuk memahami bahasa Jepang tingkat dasar.

\section{Daftar Pustaka}

Arikunto, Suharsimi. 2006. Prosedur Penelitian Suatu Pendekatan Praktik. Jakarta: PT Rhineka Cipta.

Dewi, N.M.Y., dkk. 2017. "Pengembangan Flash Berbasis Mobile Sebagai Media Latihan Nouryoku Shiken N4 Untuk Mahasiswa Tahun Pertama Jurusan Pendidikan Bahasa Jepang UNDIKSHA". Jurnal Pendidikan Bahasa Jepang, Volume 3, No 3.

Kirna,I.M. 2010. Metode Penelitian Pengembangan Pendidikan. Singaraja : Universitas Pendidikan Ganesha

Mardani, D.M.S., Sadyana, I.W., \&Adnyani, L.D.S. 2020. Learning Japanese Language Based on 2013 Curriculum at Elementary Schools in Bali.Proceedings of the

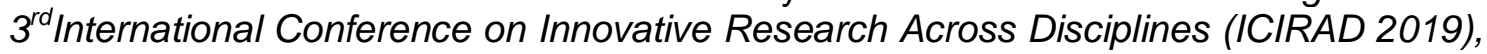
246-251.https://dx.doi.org/10.2991/assehr.k.200115.040 
Mulyatiningsih, E. 2016. "Pengembangan Model Pembelajaran". Tersedia pada: http://staff.uny.ac.id/sites/default/files/pengabdian/draendangmulyatiningsihmpd/7cp engembangan-model-pembelajaran.pdf (diunduh tanggal 12 juni 2019)

Setiani, Rina. 2015. "Pengembangan Media Pembelajaran Mengapresiasi Teks Cerita Pendek Berbasis Adobe Flash Cs5 Untuk Kelas XI SMA". Universitas Negeri Yogyakarta. Tersedia pada https://eprints.uny.ac.id/16838/1/Rina\%20Setiani/\%2010201244033.pdf. (diunduh pada tanggal 2 Oktober 2019)

Wardoyo dan Ma'arif. 2015. "Pengembangan Media Pembelajaran Berbasis Video Animasi Pada Mata Pelajaran Mekanika Teknik di SMK Negeri 1 Puworejo". Jurnal Pendidikan Teknik Sipil dan Perencanaan .

Widayat, W. 2018. "Implementasi Pengembangan Kecakapan Abad 21 Melalui Fitur Kelas Maya Portal Rumah Belajar". Tersedia pada http://pena.belajar.kemdikbud.go.id/2018/09/implementasi-pengembangankecakapan-abad-21-melalui-fitur-kelas-maya-portal-rumah-belajar/ (diakses tanggal 5 Agustus 2019) 